\title{
Christopher Colclough
}

\section{Introduction}

It would be difficult for the first two decades of any country's post-independence history to stand in starker contrast than is the case with Zambia. The economy grew rapidly during the 1960s and early 1970s, with high and rising copper exports providing the basis for buoyant government revenues and expenditures. In 1975, however, the long period of strong copper prices came to an end, reflecting, inter alia, growing excess world supplies. The price fell from over 90 cents per $\mathrm{lb}$ in 1974, to around 50 cents in 1975. Zambia's terms of trade were halved over the same period. The price has not, since then, substantially recovered.

The pattern and level of subsequent production are summarised in Table 1. Output, valued in constant prices, peaked in 1974, and remained stable at that level through 1985. However, after taking account of Zambia's terms of trade, it can be seen that real income declined sharply over those ten years. An even more dismal picture is revealed after allowing for population growth: real income per capita declined massively, so that, by 1985 , it was scarcely more than half the level reached in 1970. This article addresses three main questions:

a) Why did this happen, and could it have been avoided?

b) What adjustment measures were introduced by the Zambian authorities and what have been their effects?

c) What were the causes of Zambia's subsequent rejection of policy reform?

\section{Causes of Zambia's Economic Decline}

The enormous magnitude of the fall in the copper price is the clear cause of most of Zambia's present difficulties. The average real price of copper on the London Metal Exchange fell by one quarter over $1974 / 76$, as compared with $1970 / 72$. Table 2 shows that this real price decline continued over the following decade, so that by $1984 / 85$ it stood at only 40 per cent of its real $1970 / 72$ value. The effects of the price decline were exacerbated in the Zambian case by declining ore grades and technical production difficulties. These led to lower export volume, reducing total real export revenues from copper, by 1985, to below 30 per cent of 1970/72 levels (Table 2).

In an economy which depended upon copper for 93 per cent of its exports and up to 40 per cent of its GDP in the early 1970 s, these events were momentous. Real domestic income was cut by one quarter in 1975. This was inescapable. The interesting question, however, is whether the stagnation over the following decade was also an inevitable consequence of the copper price fall. Would alternative policies have been capable of returning Zambia to a growth path - albeit from a lower income base? Answering this question involves an examination of the policy response by the Zambian Government (GRZ) to the copper price fall, and to the balance of payments problems so created; further it involves asking whether more appropriate policies were available (i.e. techically and politically feasible) which held promise of 'better' results.

From a fairly comfortable position on its overall balance of payments in 1974, Zambia swung sharply into deficit on both current and capital accounts the following year. The former amounted to approximately 30 per cent of GDP (Table 3), and necessitated urgent action. In the short term the government had few alternatives to financing the deficit by increasing its borrowing from bilateral and multilateral sources and by running down its reserves of foreign exchange. The latter were reduced to less than K $100 \mathrm{mn}$ - sufficient at that time to finance only about eight weeks of imports - yet this source provided sufficient finance to cover only about 10 per cent of the current account deficit. Accordingly, the disbursement of medium and long-term loans increased four-fold in 1975, with the remainder of the overall deficit being covered mainly by incurring arrears on interest payable on earlier loans.

This short-term strategy, inevitable though it was, itself presented fresh dangers for the longer term. Any large increase in external indebtedness carries the implication of enhanced future debt-service outflows, which themselves need to be financed. It was a strategy, therefore, which would be containable only if the fundamental external earnings/expenditure balance were to be corrected fairly quickly. In the event, this proved difficult to achieve. The decline in the price of copper turned out to be sustained, rather than to 


\begin{tabular}{|lccccccc|}
\hline & 1970 & 1974 & 1975 & 1980 & 1983 & 1984 & 1985 \\
\hline Agriculture & 136.1 & 150.5 & 157.0 & 166.4 & 172.3 & 181.9 & 198.7 \\
Mining & 460.3 & 474.3 & 427.9 & 398.7 & 446.5 & 402.8 & 381.4 \\
Industry & 235.0 & 339.4 & 345.0 & 326.8 & 346.7 & 349.7 & 366.4 \\
Other & 437.1 & 509.7 & 508.2 & 525.9 & 506.9 & 500.8 & 513.0 \\
\hline GDP (market prices) & 1268.5 & 1473.9 & 1438.1 & 1417.8 & 1472.4 & 1435.2 & 1459.5 \\
$\quad$ Plus T/T & & -104.7 & -387.2 & -367.3 & -427.1 & -350.0 & -360.0 \\
$\quad$ adjustment & & 1369.2 & 1049.9 & 1050.5 & 1045.3 & 1085.2 & 1099.5 \\
GDYb & 1268.5 & 13.5 & & & & \\
\hline Population (000's) & 4159 & 4700 & 4846 & 5647 & 6285 & 6500 & 6725 \\
GDP per capita (K) & 305 & 314 & 297 & 251 & 200 & 191 & 190 \\
GDY per capita (K) & 305 & 291 & 217 & 186 & 166 & 167 & 163 \\
\hline
\end{tabular}

Notes: ${ }^{\text {a }}$ Rough estimates for 1984 and 1985.

${ }^{\mathrm{b}}$ Gross domestic income: this is equal to GDP plus adjustment for variations in the terms of trade.

Sources: Calculated on the basis of data in World Bank 1984, Tables 2.02 and 2.04 and World Bank, 1986a, Tables 2.02 and 2.04 .

Table 2

Copper Exports and Prices 1970-85

\begin{tabular}{|lccc|}
\hline Year & $\begin{array}{c}\text { Exports } \\
\text { (O00 tonnes) } \\
(1)\end{array}$ & $\begin{array}{ccc}\text { LME Copper Price } \\
\text { a }\end{array}$ & $\begin{array}{c}\text { Export value as } \\
\text { \% of } 1970 / 72^{\mathrm{b}}\end{array}$ \\
\hline $1970 / 72$ (average) & 677 & $12)$ & 100 \\
$1974 / 76$ (average) & 687 & 109 & 75 \\
$1979 / 81$ (average) & 609 & 87 & 53 \\
1982 & 607 & 67 & 41 \\
1983 & 551 & 74 & 41 \\
1984 & 530 & 60 & 32 \\
1985 & 479 & 61 & 29 \\
\hline
\end{tabular}

Notes: ${ }^{\text {a }}$ Price as quoted at London Metal Exchange, expressed in US cents per pound, converted to 1982 constant dollars. ${ }^{\mathrm{b}}(\mathrm{Col}(1) \times \mathrm{Col}(2)) /(1970 / 72 \mathrm{Col} 1 \times \mathrm{Col} 2) \times 100$

Source: World Bank 1986a, Table 3 (Columns I and 2). 


\begin{tabular}{|c|c|c|c|c|c|c|c|c|}
\hline & 1974 & 1975 & $\begin{array}{l}1978-80 \\
\text { (average) }\end{array}$ & 1981 & 1982 & 1983 & 1984 & 1985 \\
\hline \multicolumn{9}{|l|}{ Current items } \\
\hline $\begin{array}{l}\text { Exports } \\
\text { (of which : copper) }\end{array}$ & $\begin{array}{c}1397 \\
(1300)\end{array}$ & $\begin{array}{c}800 \\
(732)\end{array}$ & $\begin{array}{c}1259 \\
(1014)\end{array}$ & $\begin{array}{l}1000 \\
(866)\end{array}$ & $\begin{array}{c}923 \\
(799)\end{array}$ & $\begin{array}{c}992 \\
(859)\end{array}$ & $\begin{array}{c}883 \\
(723)\end{array}$ & $\begin{array}{r}829 \\
(646)\end{array}$ \\
\hline Imports & 793 & 945 & 989 & 1238 & 1158 & 839 & 742 & 752 \\
\hline Trade balance & 604 & -145 & 270 & -238 & -235 & 153 & 141 & 77 \\
\hline $\begin{array}{l}\text { Services (net) } \\
\text { (of which : interest) }\end{array}$ & $\begin{array}{l}-538 \\
(126)\end{array}$ & $\begin{array}{l}-536 \\
(117)\end{array}$ & $\begin{array}{l}-327 \\
(191)\end{array}$ & $\begin{array}{l}-468 \\
(210)\end{array}$ & $\begin{array}{l}-373 \\
(250)\end{array}$ & $\begin{array}{l}-357 \\
(252)\end{array}$ & $\begin{array}{l}-394 \\
(277)\end{array}$ & $\begin{array}{l}-217 \\
(121)\end{array}$ \\
\hline Current transfers (net) & -61 & -61 & -84 & -157 & -91 & -55 & -51 & -51 \\
\hline Current account balance & 5 & -742 & -141 & -863 & -699 & -259 & -304 & -191 \\
\hline \multicolumn{9}{|l|}{ Capital items } \\
\hline Grants & 9 & 5 & 30 & 27 & 40 & 36 & 53 & 71 \\
\hline Medium and long term loans (net) & 105 & 382 & 269 & 208 & 258 & 104 & 212 & 209 \\
\hline Net IMF flows & - & 23 & 96 & 368 & -57 & 64 & 76 & -97 \\
\hline $\begin{array}{l}\text { Other capital, plus } \\
\text { errors/omissions }{ }^{a}\end{array}$ & \multicolumn{4}{|c|}{ Other capital, plus } & -19 & -207 & -401 & -574 \\
\hline Overall balance & 12 & -158 & -43 & -47 & -477 & -262 & -364 & -582 \\
\hline $\begin{array}{l}\text { Arrears (- means reduction) } \\
\text { Debt relief/Exceptional }\end{array}$ & - & 158 & 43 & 47 & 477 & -51 & -118 & 567 \\
\hline financing & - & - & - & - & - & 313 & 482 & 15 \\
\hline \multicolumn{9}{|l|}{ Memorandum } \\
\hline Current A/C deficit/GDP (\%) & - & 29.7 & 4.2 & 22.1 & 18.1 & 7.7 & 11.1 & 8.1 \\
\hline
\end{tabular}

Note: "Includes arrears on external payments and on debt service, reserve changes, gold revaluation and SDR allocations.

Sources: World Bank 1984 Table 2.1, 1986a, Tables 5 and 3.01.

represent a short-term fluctuation which was subsequently reversed. Thus, real export revenues continued to fall. Furthermore, the rising price of oil exacerbated the difficulties on current account: the real value of exports (i.e. adjusted for changes in import prices) was halved between 1974 and 1975 and it was halved again by 1983 [see Table 4].

In principle, when a payments deficit appears to become endemic, rather than transitory, a government confronts a range of instruments which can be used to move the economy back towards equilibrium. Elementary theory demonstrates that an improvement in the current account of the balance of payments requires that domestic absorption of resources $(C+I)$ be reduced relative to income. In circumstances where income is not growing, consumption or investment or both must fall, if more resources are to be released for export, or if imports are to be reduced. Alternatively, 'adjustment through growth' - via export promotion or import substitution - would allow correction of the balance of payments deficits without concomitant reductions in domestic expenditure. In most countries, however, this can only make sense as part of a longterm strategy; and it is not much help as a palliative when deficits represent a sizeable portion of GDP. In Zambia's case (though such a strategy may be judged desirable per se) it was particularly unpromising as a solution to its payments problem. This, it should be recalled, was caused by a 25 per cent fall in current income. Yet, the physical amount of production - 


\begin{tabular}{|lcccccc|}
\hline & 1970 & 1974 & 1975 & 1976 & 1980 & 1983 \\
\hline Gross domestic income & 1268.5 & 1369.2 & 1050.9 & 1053.5 & 1050.5 & 1052.0 \\
\hline $\begin{array}{l}\text { (Plus) Imports } \\
\text { (Less) Capacity to import }\end{array}$ a & 470.5 & 488.3 & 454.9 & 339.4 & 291.0 & 157.3 \\
(Less) Statistical discrepancy & 685.4 & 602.0 & 296.0 & 383.7 & 261.3 & 153.5 \\
\hline Gross domestic expenditure & 1053.6 & 1255.6 & 1279.7 & 1056.3 & 1067.4 & 1066.0 \\
\hline Gross domestic consumption & 692.8 & 760.1 & 852.4 & 827.5 & 861.4 & 930.7 \\
\hline $\begin{array}{l}\text { Government } \\
\text { Private }\end{array}$ & 198.5 & 259.0 & 287.2 & 291.9 & 272.5 & 241.6 \\
\hline Gross domestic investment & 494.3 & 501.1 & 565.2 & 535.6 & 588.9 & 689.2 \\
\hline $\begin{array}{l}\text { Fixed capital formation } \\
\text { Changes in stocks }\end{array}$ & 360.8 & 495.5 & 427.3 & 228.8 & 206.0 & 135.3 \\
\hline
\end{tabular}

Note: ${ }^{a}$ Defined as exports, in current prices, divided by the import price index $(1970=1.0)$.

Sources: Central Statistical Office, Monthly Digest of Statistics, and GRZ documentation for Consultative Group.

and therefore the aggregate need for imports - was the same post- and pre-1975. The process of restoring the 25 per cent value loss via import-constrained production increases was surely always a hopeless task - at least over the short-to-medium terms.

An alternative set of instruments to those focusing upon domestic expenditure variables is provided by the external sector itself. The two broad category choices concern policies which affect prices, via, for example, manipulation of the exchange rate, or of import duties, and those which directly affect quantities by introducing administrative controls on imports, or on access to foreign exchange. Again in principle, in a world of flexible coefficients and high substitution elasticities for the use of factors in production and products in consumption, freely adjusting the domestic/international price ratio in response to fluctuations in foreign or domestic demand should be enough to preserve payments equilibrium by encouraging a greater domestic production of tradeable goods. But this is so only in the context of small changes in either price or demand. ${ }^{1}$ Even with flexible coefficients, valuation changes of the magnitude experienced by Zambia's major export commodity could not be easily or speedily compensated by policies restricted to operation on relative prices. This is true both as regards the required additional production of importsubstitutes or of exports. For example, in terms of the availability of technology, resources and market size, a switch from foreign to domestic sources of supply is simply not a medium-term possibility for much of Zambian mining and manufacturing industry. Equally, given the uncertainties surrounding the copper industry, adjustment through export production would mainly have to comprise increases in so-called 'non-traditional' exports - particularly agricultural and manufactured goods. Yet, even high supply elasticities in these sectors could hardly deliver sufficient production response strongly or quickly enough to replace copper losses - even taking a tenyear view.

Of course, even under the above circumstances, a devaluation can still achieve adjustment via the changes to the distribution of income (away from consumers, towards producers) which it imposes. The

\footnotetext{
'For further discussion of this point see Harvey's article in this issue.
} 


\begin{tabular}{|c|c|c|c|c|c|c|c|c|c|c|}
\hline & 1974 & 1975 & 1976 & 1978 & 1980 & 1981 & 1982 & 1983 & 1984 & 1985 \\
\hline \multirow{3}{*}{$\begin{array}{l}\text { Total expenditure (current } \\
\text { Kwacha, millions) } \\
\text { (constant } 1975 \text { Kwacha, } \\
\text { millions) }\end{array}$} & & & & & & & & & & \\
\hline & 612.2 & 855.0 & 771.5 & 815.4 & 1302.0 & 1388.6 & 1470.6 & 1442.1 & 1621.0 & 2945.7 \\
\hline & 663.3 & 855.0 & 678.5 & 497.8 & 608.1 & 553.2 & 520.4 & 436.6 & 450.7 & 649.4 \\
\hline \multicolumn{11}{|l|}{ As percent of total expenditure } \\
\hline Wages & 20.5 & 17.9 & 22.9 & 23.2 & 19.7 & 25.4 & 24.2 & 27.9 & 28.2 & 18.4 \\
\hline Debt service & 11.6 & 8.9 & 13.7 & 19.2 & 14.3 & 14.1 & 15.7 & 17.1 & 17.9 & 28.5 \\
\hline Total current expenditure & 72.0 & 71.3 & 78.9 & 79.4 & 83.1 & 88.6 & 84.5 & 86.3 & 83.6 & 84.5 \\
\hline Capital expenditure & 28.0 & 28.7 & 21.1 & 20.6 & 16.9 & 11.4 & 15.5 & 13.7 & 16.4 & 15.5 \\
\hline Tax revenue & 97.5 & 45.7 & 49.6 & 59.2 & 54.0 & 53.7 & 50.6 & 65.3 & 61.1 & 47.0 \\
\hline Total revenue and grants & 112.8 & 55.7 & 61.0 & 71.7 & 62.1 & 61.3 & 59.0 & 74.2 & 71.1 & 57.5 \\
\hline Deficit & -12.8 & 44.3 & 39.0 & 28.3 & 37.9 & 38.6 & 41.0 & 25.9 & 28.4 & 42.6 \\
\hline Financed by: & & & & & & & & & & \\
\hline External loans & 9.5 & 11.8 & 6.9 & 7.4 & 10.6 & 20.1 & 13.1 & 10.7 & 7.9 & 7.0 \\
\hline Bank of Zambia & -27.0 & 27.7 & 24.6 & 15.8 & 22.3 & 12.2 & 33.3 & 8.0 & 11.7 & 6.4 \\
\hline Other ${ }^{a}$ & - & 4.8 & 7.5 & 5.1 & 5.0 & 6.4 & -5.5 & 7.2 & 8.8 & 20.7 \\
\hline \multicolumn{11}{|l|}{ As percent of GDP } \\
\hline Total expenditure & 32.3 & 54.0 & 41.2 & 36.4 & 43.2 & 40.3 & 40.9 & 34.5 & 32.9 & 46.5 \\
\hline Tax revenue & 31.5 & 24.7 & 20.4 & 21.6 & 23.3 & 21.6 & 20.7 & 22.5 & 20.1 & 21.9 \\
\hline Total revenue and grants & 36.5 & 30.1 & 25.1 & 26.1 & 26.8 & 24.7 & 24.1 & 25.6 & 23.5 & 26.7 \\
\hline Deficit & -4.2 & 23.9 & 16.1 & 10.3 & 16.4 & 15.6 & 16.8 & 8.9 & 9.3 & 19.8 \\
\hline Borrowing from $\mathrm{BOZ}$ & -8.7 & 15.0 & 10.1 & 5.8 & 9.6 & 4.9 & 13.6 & 2.8 & 3.8 & 6.9 \\
\hline Government savings & 13.2 & -8.4 & -7.4 & -2.8 & -9.1 & -11.0 & -10.4 & -4.2 & -3.9 & -9.3 \\
\hline
\end{tabular}

Note: " Includes debt relief in 1982, 1983 and 1985.

Sources: Annual Financial Reports, GRZ, and World Bank 1986a, Table 5.01. CSO: Implicit Gross Domestic Expenditure deflator, from national accounts.

net effects are often difficult to anticipate, since, ultimately, the incomes of the two groups are mutually dependent. But, initially, at least such re-distribution tends to promote export production and to reduce import demand. This, however, has as much to do with adjusting via reductions in consumption, as it has to do with the size of the relevant supply elasticities.

Similar points can be made about direct controls upon foreign exchange, or imports. In principle, such controls allow the possibility of eliminating the deficit by reducing the import of 'unnecessary' items. This instrument allows much greater selectivity than is possible with the use of the exchange rate alone. The dangers, however, are well known: inefficiencies in allocation causing production bottlenecks; overvaluation of the exchange rate reducing incentives to export; and the difficulty of dealing with large payments deficits - such as that in Zambia - via import controls alone.

GRZ's response to the payments deficit involved use of each of the above instruments. The particular combination of measures adopted, however, did not succeed in eliminating the deficit. As shown in Table 4, the increased severity of the import constraint reduced domestic expenditure after 1975. The table seems to suggest that the entire burden of reduction fell on investment. Consumption, on the other hand, continued to rise. The table does not, however, allow for population growth. Such incorporation reveals that consumption per capita had, by 1983 , fallen by 16 per cent in comparison with $1975 .{ }^{2}$ Nevertheless the cuts in investment were very sharp indeed ( 80 per cent over 1974/83) and this would have drastically reduced the possibility of a return to economic growth, even from the depressed levels of the mid-1970s.

The behaviour of government spending is of particular interest. Its main constituents over the period are shown in Table 5 . It should be noted that total spending by central government was halved in real terms between 1975 and $1983 / 84$, but that current spending fell much less sharply. (Although real wages fell, debt service rose to take their place in budgetary

It is interesting to note that this fall in living standards, indicated by the macroeconomic data, almost exactly corresponds to the fall in the real value of the government minimum wage over the same period, shown in Table 7. 
terms.) Capital expenditure was severely cut - falling by 70 per cent over the period. The public sector deficit was higher than one-third of total spending for most of these years. The deficit had emerged primarily owing to reduced mining revenues, and was financed partly by borrowing from the Central Bank, and partly by foreign borrowing, both of which tended to aggravate the size of the external payments deficit.

As regards the external sector, a range of policies were pursued to encourage export diversification and import substitution - some representing a continuation of policies which were in place well before 1975. Initially, the main instrument of protection was a highly differentiated tariff structure, which set very high tariffs on consumer - and particularly luxury -goods, and very low rates on capital and intermediate goods. After 1975, however, when the serious shortage of foreign exchange set in, GRZ established an elaborate system of import licensing and foreign exchange allocation. Every import required a licence from the Ministry of Commerce and Industry, and a foreign exchange allocation from the Bank of Zambia. In practice the system grew complex and unwieldy. Allocations of foreign exchange and of licences were often arbitrary as between different industrial branches, and between different firms in the same branch. The impact of the overall shortage of foreign exchange was, therefore, often exacerbated by inefficiencies and delays in its allocation.

The exchange rate, fixed by GRZ, was gradually reduced after 1975. By 1982 it had fallen to approximately two-thirds its level (relative to the US dollar) of the mid-1970s (Table 6). Domestic inflation, on the other hand, was high during these years - the CPI increased by about 150 per cent over the period. Thus - at least relative to the mid-1970s - the Kwacha appeared to become increasingly overvalued. A symptom of this was the development of a parallel market, where the unofficial exchange rate was considerably lower than the official rate. Unfortunately, therefore, these circumstances served to decrease the incentives to export, or to manufacture import substitutes, as compared with the early 1970 s.

In response to the high, and rising, inflation rate, GRZ increased the administrative regulation of consumer prices, and extended the subsidies on basic commodities. One result of these controls, however combined with the inefficiencies in foreign exchange rationing and associated shortages of raw materials and spare parts - was reduced profitability of domestic industry and a further contraction of investment and maintenance expenditures. Large sections of industry were operating at less than full capacity (some sources put average capacity utilisation during the early 1980 s no higher than 30 per cent), whilst transport and marketing bottlenecks prevented the effective distribution of those commodities which were available. Exchange rate overvaluation also provided few incentives for 'non-traditional' exports. A symptom of this is that whilst copper production fell from 33 to 15 per cent of GDP between 1970 and 1983 , its share of exports declined hardly at all; meanwhile,

\section{Table 6 Average Annual Kwacha/Dollar Exchange Rates and Inflation: Selected Years}

\begin{tabular}{|c|c|c|c|c|c|}
\hline & & Urbo & $C P I$ & Annual \% c & ange in $C P I$ \\
\hline & US\$ per Kwacha & Low Income & High Income & Low Income & High Income \\
\hline 1970 & 1.40 & & & & \\
\hline 1975 & 1.55 & 100.0 & 100.0 & 10.1 & 8.5 \\
\hline 1980 & 1.27 & 202.9 & 189.4 & 11.7 & 11.9 \\
\hline 1981 & 1.15 & 231.3 & 209.1 & 14.0 & 10.4 \\
\hline 1982 & 1.08 & 260.2 & 236.7 & 12.5 & 13.2 \\
\hline 1983 & 0.80 & 311.2 & 278.6 & 19.6 & 17.7 \\
\hline 1984 & 0.56 & 373.5 & 336.8 & 20.0 & 20.9 \\
\hline 1985 & 0.37 & 513.5 & 455.0 & 37.5 & 35.1 \\
\hline 1986 July-Sept & 0.16 & 778.4 & 707.2 & 51.6 & 55.4 \\
\hline $\begin{array}{c}1987 \text { April } \\
\text { May }\end{array}$ & $\begin{array}{l}0.05 \\
0.125\end{array}$ & 938.3 & 850.5 & 21.0 & 21.0 \\
\hline
\end{tabular}

Note: From October 1985 onwards the value of the Kwacha was determined at a weekly auction of foreign exchange. Wide fluctuations took place during 1986. The value shown is the average value obtaining in the months July-September. Further deterioration took place. The lowest value reached is that shown for April 1987. As from May 1987 the auction was suspended, and the Kwacha's value was pegged at $\$ 0.125$ US. CPI figures for 1987 are for the month of January. High Income index for January 1987 calculated on basis of Low Income index (assuming increase over 1986 was the same proportion in both cases).

Sources: World Bank 1986a, Bank of Zambia 1985 and Central Statistical Office. 
agricultural exports fell to almost zero over the period. By consequence these measures did little or nothing to ameliorate the situation. On balance they made matters significantly worse. Although imports were increasingly held back - falling by two-thirds in real terms between 1974 and 1983 (Table 4) - the sustained decline of the copper price implied a continuation of serious current account deficits throughout the period. These continued to be financed by borrowing. Contraction of medium and long-term public and publicly guaranteed external loans increased from an annual average of US $\$ 235 \mathrm{mn}$ in 1975-77 to almost $\$ 700 \mathrm{mn}$ in 1979 and 1980 . In 1981 and 1982 they averaged just over $\$ 400 \mathrm{mn}$ increasingly from non-concessional, private sources with the terms of such lending gradually hardening. Accordingly, debt service obligations mounted sharply. In 1974 debt service payments had represented less than 8 per cent of export earnings, and had risen to 20 per cent by $1978-81$. But by 1983 , debt service obligations due were estimated at US $\$ 550 \mathrm{mn}$, or 52 per cent of export earnings, exclusive of arrears of almost US $\$ 1 \mathrm{bn}$. This situation was untenable and necessitated GRZ reaching urgent agreement with its major creditors on debt-rescheduling, on new finance, and on the conditions that would be attached to such resource flows.

\section{Economic Reforms 1983-87}

From around 1981 there had been signs of policy change on the part of GRZ. This reflected the frequency of negotiations with the IMF, as Zambia's balance-of-payments problems intensified. Finance was provided by the Fund in 1978 and 1981, from its upper tranche facilities, which involved the acceptance by GRZ of a range of stabilisation measures. All were not, however, implemented, and the failure to meet performance targets led to a cancellation of the 1981 Stand-by by the Fund in the following year.

As indicated, however, by 1983 Zambia had become more dependent upon securing agreement not only with the Fund but with the aid community as a whole. In particular the process of reaching accommodations with the World Bank and the IMF had become interdependent. The Bank was increasingly the most visible and articulate of the aid agencies. Its documentation and analysis of the problems confronting Zambia was extensive and persuasive. Many bilateral agencies appeared willing to follow the Bank's lead, and be strongly influenced by its interpretation of Zambian policy requirements and performance. Increasingly the aid community insisted that the government should introduce significant economic reforms if their finance were to assist a process of recovery rather than simply postponing further decline.

In response to these pressures, and following a protracted dialogue with the Fund and the World Bank, the government was persuaded to introduce a far-reaching set of economic reforms which were believed capable of achieving structural change and diversification of the economy and a reduction in its dependence on foreign exchange. These reforms were discussed at the World Bank-sponsored Consultative Group meetings in 1984, where they received the support of the wider donor community, and pledges of additional financial assistance. Their main elements were: exchange rate devaluation of 60 per cent, which resulted over the two years ending in July 1985 in a 40 per cent real depreciation of the Kwacha; reductions in government spending - expenditure on consumer subsidies and capital items were cut and a freeze on recruitment to the administrative cadre of the public service was introduced; the level of taxation on mineral exports was increased. These measures were strengthened by approximately $\$ 400 \mathrm{mn}$ of debt re-scheduling on the part of the government's creditors. In addition, a range of policy reforms was announced in each of the mining, agricultural and industrial sectors, aimed at improving their efficiency and output. Rehabilitation loans to each of these sectors were announced by consortia of donors, and made conditional on the policy reforms being implemented.

During 1984 a new Stand-by credit of SDR $225 \mathrm{mn}$ had been agreed with the IMF. But in early 1985 drawings were suspended after only SDR $80 \mathrm{mn}$ had been used. Once again, performance criteria could not be satisfied - in particular the pace of exchange rate depreciation was less rapid than the IMF wished; furthermore, GRZ was unable to maintain interest payments and had proved unwilling to reduce consumer subsidies to the extent previously agreed. Negotiations on these and other matters continued during 1985. In October, however, the government introduced a series of radical measures that eventually succeeded in winning IMF support: interest rates were decontrolled and agricultural producer prices were substantially raised; the centrepiece of the new measures, however, was the introduction of a weekly auction of foreign exchange and the abandonment of import licensing. Henceforth the exchange rate was determined by market forces - on the basis of the price set by the marginal bid which succeeded in exhausting the week's offer of foreign exchange. These radical reforms were strongly favoured by the IMF and by the aid community more generally. In February 1986 a two-year Stand-by A rrangement with the IMF was announced whereby SDR $229.8 \mathrm{mn}$ would be made directly available, with a further SDR $68.8 \mathrm{mn}$ at hand under the Compensatory Financing Facility.

The IMF agreement was quickly followed in March 1986 by arrangements to reschedule $\$ 500 \mathrm{mn}$ of debts with the 'Paris Club' group of official creditors. 


\section{Effects of the Reforms}

The impact of the liberalisation measures adopted in October 1985 was far more profound than those of any of the earlier policy reforms introduced since 1983 . This was mainly because of the dramatic change in the exchange rate - and hence in the relative prices of traded, compared with non-traded, goods. In September 1985 the exchange rate had been K2.2 per US dollar. After the auction it fell to K5, and continued to fall steadily thereafter - reaching $\mathrm{K} 14$ per dollar by December 1986 .

The radical increase in the price of imports, and in the Kwacha returns from export production which followed the auction, very sharply increased the profitability of producing agricultural and manufactured goods. As regards agriculture the shift towards more market-oriented pricing policy (since 1983) had coincided also with a run of good weather. Nevertheless the extent of output response does suggest that earlier pricing policies had contributed heavily to the long period of stagnation in Zambian agriculture. It appears that value added in agriculture increased by about 8 per cent per year between 1982/3 and $1984 / 5$, with production of wheat, coffee and soya bean increasing between three and eight fold, and that of sunflowers and maize doubling, as compared with production levels of 1979. The Budget Speech of February 1987 [GRZ 1987] reported further major increases in production in $1985 / 86$. Maize output increased by 40 per cent over the preceding year, with self-sufficiency in the staple food being achieved. Further large production increases were also recorded for groundnuts, rice, wheat, millet, sorghum and soya beans.

A similarly strong response is reported from various sources for the manufacturing sector. Over the year following the inception of the foreign exchange auction, capacity utilisation increased from less than 40 per cent to about 55 per cent, factor productivity increased sharply, as did manufacturing value added - by up to 15 per cent. The Minister of Finance observed that shortages of foreign exchange continued to constrain production owing to inadequate input supplies. But the tone of the Budget Speech remained bullish, as regards the future growth of manufacturing. There were, of course, many profound problems which continued to inhibit output in both of these sectors, covering the whole spectrum of production support (technique, inputs, transport, marketing, etc.) but it would be churlish not to accept that - in the context of these constraints - price liberalisation had a strong positive impact upon output. Supply elasticities appeared to be quite high, even in the short-run.

Whilst, at one level, these developments appear to vindicate the line taken by the IMF/World Bank, and by the rest of the aid community, in their negotiations with GRZ, the sharp changes in policy which were imposed also brought very significant costs for many groups within Zambia. These costs tended to be underplayed in the analysis of the effects of liberalisation - yet, in the event, proved strong enough to undermine, and eventually to reverse, the movement for reform. At this stage, analysis is hampered by the fact that data on sectoral production, balance of payments and government finances are not yet available for $1985 / 86$ and $1986 / 87$. It is not therefore possible to analyse the short-run impact of the 1985 reforms upon the major macroeconomic aggregates. Nevertheless it appears clear that the major reasons for the eventual reversal of policy which took place in 1987 were two-fold. First, the radical change in the distribution of income imposed by the auction pauperised significant sections of the community, and imposed strains on the political system which proved impossible to bear. Second, the unwillingness of the aid community to increase concessional resource flows to Zambia significantly, meant that the logic for reneging on earlier debt repayment agreements became increasingly attractive. Each of these points are addressed in the remainder of this article.

The Labour Market. In a simple primary-goods exporting economy like Zambia, where the price of exports is fixed in terms of foreign exchange, and where most intermediate goods are imported, a judgement that the exchange rate is overvalued is basically synonymous with a view that real wages are too high. A devaluation increases the returns, in domestic currency, to exporters and to producers of import-substitutes. But these increased returns are dependent upon wages and salaries not rising to compensate fully for the increased domestic prices imposed by devaluation. A judgement, therefore, about the extent to which nominal depreciation will be capable of increasing the profitability of tradeables production is crucially dependent upon the assumptions made about the willingness of the labour force to accept cuts in their standard of living.

Conditions in the Zambian labour market had been deteriorating for some years. Formal employment in 1984 was some 10 per cent lower than it had been in 1975. This had been associated with a rapid rise in unemployment rates in the urban centres. Youth unemployment, in particular, appears to have increased massively (rates of 24-28 per cent are reported by the 1980 census for those aged $15-25$ years in urban centres). By 1986 these levels of unemployment would undoubtedly have increased still further. Those who had been lucky enough to retain, or find, a formal sector job, have also had to accept sacrifices. Although high and rapidly rising wage rates exerted great pressure on consumption and imports for some years, the peak in real earnings came around 1970 , after which formal sector workers experienced large 


\begin{tabular}{|c|c|c|c|c|c|c|c|c|c|c|c|}
\hline Scale & Post & $\operatorname{Jan} 67$ & May 71 & July 75 & $\operatorname{Jan} 79$ & Aug 80 & Jan 82 & Jan 83 & Nov 83 & Oct 85 & July 86 \\
\hline 53 & Under-Secretary & 135 & 132 & 100 & 60 & 68 & 59 & 51 & 45 & 29 & 19 \\
\hline 57 & Assistant Director & 137 & 124 & 100 & 60 & 62 & 53 & 46 & 41 & 27 & 18 \\
\hline 512 & $\begin{array}{l}\text { University graduate } \\
\text { entry }\end{array}$ & 121 & 106 & 100 & 58 & 63 & 53 & 46 & 41 & 29 & 19 \\
\hline 513 & Diploma entry & 119 & 105 & 100 & 59 & 67 & 57 & 50 & 44 & 31 & 21 \\
\hline 221 & $\begin{array}{l}\text { Lowest paid salaried } \\
\text { employee }\end{array}$ & 95 & 99 & 100 & 71 & 89 & 89 & 87 & 83 & 70 & 49 \\
\hline & $\begin{array}{l}\text { Unskilled non- } \\
\text { established }\end{array}$ & n.a. & 96 & 100 & 73 & 85 & 90 & 91 & 88 & 75 & 53 \\
\hline
\end{tabular}

Sources: GRZ 1986a; World Bank 1986b.

declines in real incomes. This is true for all sectors of the economy. Government basic starting salaries in 1983 were less than half their real 1975 levels for the more skilled groups (Table 7). Although the fall was less sharp for the unskilled groups, they too suffered a 10 per cent decline in real earnings between 1975 and 1983. These trends accelerated between 1983 and 1985 , with the real incomes of all but the lowest paid government workers dropping to below one-third of their 1975 levels. Similarly large declines in real earnings have been experienced by parastatal employees, the mining sector workers, and for most of those in the private sector as well. Even these cuts, however, were modest relative to the impact of the currency auction system, after October 1985, on levels of domestic inflation, and upon further declines in real wages. During 1986 and early 1987 prices increased by about 65 per cent, which compared with a 40 per cent increase in nominal earnings for most workers. Further cuts in real incomes of about 25 per cent were therefore incurred by most of those working in the formal sector during 1986. Zambia had, throughout the 1970s, remained a high wage economy in comparison with surrounding countries. Declines in wage costs were necessary, therefore, if industrialisation was to have much chance of being successful. But the speed and severity of the fall in the value of real earnings was so great that even early in 1986, it seemed inevitable that these welfare losses would prove unacceptable to large sections of organised labour.

It can be argued, then, that the major problem with the adjustment imposed on the economy by the auction was its speed and severity - and that some degree of real wage adjustment was both inevitable and overdue. The downward pressure upon other incomes, however, which the reductions in public expenditure, increasing unemployment and declining real wages set in train, gave separate and substantial cause for concern. A survey of low income households in Lusaka, for example, showed that the majority of poor households had, in 1986, significantly changed the composition of their diets since the auction of foreign exchange began [UNDP 1986]. In particular, the quantity of more expensive, high protein foods which had previously been bought fell, and was often substituted by mealie meal. Some of the very poorest households had also reduced purchases of staples. Female-headed households faced special poverty problems since they were often dependent upon a single, irregular income source. More generally, incomes in a large part of the informal sector were threatened by the adjustment, largely because of the sharply declining incomes of wage and salary earners, on whom informal sector workers often depended for their market. These circumstances, together with rapidly rising levels of urban unemployment as civil servants and mining workers were laid off, implied an increase in the incidence of serious poverty and deprivation in the urban centres. Opposition to the adjustment measures, when it came, would clearly not be confined to waged or salaried workers alone.

Trade Prospects and External Capital. During 1986 Zambia's trade account worsened considerably, primarily because copper prices declined further, and cobalt prices fell by 50 per cent. This prompted a reassessment of prospects for future trade recovery, which looked considerably more bleak than before. Total annual external capital requirements were projected (by both GRZ and the World Bank) to rise from about US $\$ 400 \mathrm{mn}$ in 1986 to close to $\$ 1$ bn in 1987 - considerably more than total export receipts. More than three-quarters of these financing requirements were generated by interest and principal repayment obligations on foreign debt. Both the absolute and relative importance of debt service obligations were projected to rise each year to 1989. Under these circumstances, even generous assumptions for the amount of new external capital likely to be available were dwarfed by the amounts needed by Zambia to pay back its debt. 


\section{Rejection of Reform}

By the end of 1986 the impact of the auction on levels of domestic inflation was causing GRZ increasing concern. The Consultative Group meeting, held in Paris in December, was immediately preceded by extensive rioting in the copperbelt towns following an attempted doubling of the price of maize-meal by the government, as part of its commitment to remove consumer subsidies. These events had an undoubted impact upon the resolution of the government to proceed in the ways suggested by the IMF and other lenders. In spite of the government's stated commitments to maintain existing reforms, a series of sharp changes in economic policy soon followed the meeting of the Consultative Group. At the end of January 1987 the price of the K wacha was pegged, in a range of K9-K 12.50 per dollar - to be determined, within that range, by auction bids. However, early in February the weekly auctions were postponed pending further discussions with the IMF and the World Bank. Following these discussions in late March a two-tier exchange rate system was announced. The first, covering official aid transactions, debt servicing, and the procurement of medical and educational supplies would be within the range of K9-K 12.50 per US dollar. All other transactions were to be determined by the auction, as before.

Political difficulties re-emerged, however. The auctiondetermined rate for the Kwacha continued to fall sharply; strikes by increasing numbers of workers, and criticism of the harshness of the adjustment measures became more frequent. Price rises appeared to accelerate weekly, and the exchange rate fell to K21 per US $\$ 1$ in late April. On 1 May President Kaunda announced that negotiations with the IMF were ended forthwith, and that the reform programme was suspended. The currency auction was discontinued, and a fixed rate of $\mathrm{K} 8$ to the dollar was imposed. Debt service payments would henceforth be limited to 10 per cent of export earnings net of the foreign exchange needs for mining imports, the Airways, fuel and fertiliser imports. Interest rates were cut by five per cent and price control was re-introduced. This, then, represented a return to the old policy regime.

\section{Conclusion}

The Zambian adjustment story has classic features. Its adjustment imperatives were externally determined caused by massive deterioration in the price commanded by its only significant export. In view of adverse external conditions, where access to grant monies could not bridge the gap, the government reacted to its fall in reserves and revenues too little and too late. Investment fell much more sharply and quickly than consumption, and external borrowing increased massively. This reduced its ability, at a later stage, to adjust via growth, since a large part of export revenues had already been pre-empted by debt service obligations.

Aid agencies were justified in attaching conditions to their resource flows, because GRZ policy did need to change. Unfortunately, however, they were the wrong conditions. Specifically the Fund and the Bank (and by implication, all other CG members) pushed Zambia too hard and too fast. The extent to which they pauperised the wage earning classes, and pushed many at the fringes of the formal economy into starvation and destitution almost guaranteed that the reforms would become untenable. The speed and extent of enforced structural change was greater than the fabric of the polity would allow. Kaunda - faced with circumstances on external account where things could hardly deteriorate further - had little to lose, and much domestic popularity to gain, by turning his back on the IMF.

It is too early yet to identify the likely economic impact of the new measures. A key variable in the country's short-run prospects is the reaction of the aid community. Severance of all aid inflows has not happened, but a sharp cut-back appears to have occurred. A return to a price-control, subsidy and import licensing regime of economic management may contain the political pressures, but is unlikely to improve diversification prospects. On the other hand, this may be more likely if the exchange rate of $\mathrm{K} 8$ to the dollar (which retains greater incentives for export as compared with the rate pre-1986, notwithstanding subsequent inflation) is held.

The main lessons of this recent history are, however, for the aid community. They underline the enormous risks of pushing a country farther and faster than its social and political framework will allow. The costs can be measured in lost economic opportunities for years to come - and, more harshly and directly, in lost human lives.

\section{References}

Bank of Zambia, 1985, Quarterly Financial and Statistical Revien', vol 15 no 1, Lusaka

GRZ, 1986a, Consumer Price Statistics, Central Statistical Office, January and October

-1986b, Budget Address, Government Printer, Lusaka

- 1987, Budget Address, Government Printer, Lusaka

UNDP, 1986, Restructuring and Development in Zambia: Roles for Technical Cooperation, New York

World Bank, 1984, Zambia: Country Economic Memorandum. Issues and Options for Diversification, Washington DC

-1986a, Zambia: Country Economic Memorandum. Economic Reforms and Development Prospects, Washington DC

-1986b, "Wage Policy and the Structure of Wages and Employment in Zambia' (O. Meesook et al.) CPD Discussion Paper, Washington DC 